\title{
The Impact of Generational Status on Instructors' Reported Technology Usage
}

\author{
Susan Troncoso Skidmore, Linda Reichwein Zientek, D. Patrick Saxon, \& Stacey L. Edmonson \\ Sam Houston State University, United States
}

\begin{abstract}
Although the majority of colleges and universities are equipped with the latest instructional technologies, an appreciable integration of technology has not been observed in instructional practices (Flavin, 2013; Garrison \& Akyol, 2009; Salinas, 2008). The purpose of this research is to understand the impact that generational differences can have on developmental education faculty members' self-reported familiarity, use, and challenges with instructional technology as measured by the Developmental Education Technology Survey (DETS; Skidmore, Saxon, Zientek, \& Edmonson, 2012). The DETS was developed to examine the level of technology integration in developmental education programs across Texas higher education institutions. Responses from 753 developmental education faculty members from 68 institutions (69\% institutional response rate) are the focus of this study. Findings suggest that generational classification serves as a statistically significant predictor of familiarity with instructional technology. A statistically significantly larger proportion of the faculty of the Silent generation also identified their own skill level as a challenge compared to other generations. Developing an understanding of faculty members' proclivity to use instructional technology through the lens of generational classification can lead to more targeted professional development, which can help faculty members move towards using instructional technology as a resource to improve teaching and learning.
\end{abstract}

Keywords: Generational status; Developmental education; Integration of technology; Technology usage

\section{Introduction}

Instructional technology has become a "permanent, respected and increasingly essential component of the college experience" (Green, 1996, p. 24). Although higher education course instructors are well versed in the concepts and content of what they are teaching, in general, faculty members have not responded to the ubiquitous nature of technology by radically transforming their teaching practices (Garrison \& Akyol, 2009; Green, 1996; Salinas, 2008). In the field of developmental education, sweeping reform is placing more emphasis on technology-based methods of delivering instruction and academic support. For example, Texas House Bill 1244 (2011) specifically requires developmental education instructors to provide instructional supports for students including "the integration of technology to efficiently address the student's particular developmental needs" (para. 2). Some colleges have experimented with technology-based 
instruction for developmental mathematics courses such as the Emporium Model where students are engaged with digitized content in computer labs as an alternative to traditional classroom instruction (Boatman, 2014).

The impact of instructional technology mandates in developmental instruction may prove challenging in American open-access education. Developmental education courses are designed to serve academically underprepared college students and are offered at nearly all 2-year colleges in the United States (National Center for Education Statistics, 2003). Instructors in these developmental education courses are charged with teaching and providing support necessary to help students become successful in college-level, credit-bearing courses. However, many developmental education instructors have likely entered the profession with extensive content area knowledge, yet little to no experience or training in instructional methods (Boylan, 2009), let alone in the use of technology to facilitate student learning (as is likely the case for many college faculty). In addition, the majority of developmental education instructors are part-time faculty (Shults, 2001). This is important to consider because part-time faculty are more likely to operate at the periphery of an institution's core activities (Schibik \& Harrington, 2004) and therefore less likely to be engaged in a systematic process of instructional development, inquiry, and improvement.

Various factors have been thought to affect the integration of technology into the classroom by instructors. In the United Kingdom, researchers exploring the introduction of Electronic Voting Systems (also known as Student Response Systems or "Clickers") noted four components that directly influenced technology usage: Performance expectancy, effort expectancy, social influence, and facilitating conditions (Jeffries, Cubric, \& Russell, 2013). Performance expectancy considers how the technology will make work life easier, i.e., the usefulness of the technology. Effort expectancy is related to ease of use. Social influence considers whether the user is expected to use the technology. Facilitating conditions are the organizational and technical systems that support technology usage. Meyer and $\mathrm{Xu}$ (2007) found that instructional workload and responsibilities were an important factor influencing the adoption and use of technology by faculty. Too much emphasis on the technology itself (Salomon, 2002) and the lack of support for faculty (Merrill, 2002) were other important obstacles that suppressed the effective application of instructional technology.

It appears there have been many challenges associated with the training and development needed to support technology use in the classroom. In a national survey of college students, faculty, and administrators, the top challenge cited in the use of campus technology was a lack of knowledge about technology on the part of faculty (CDW-G, 2011). Similarly, Surry and Land (2000) noted a higher education problem area was that faculty members were not aware of technology tools and how to use these tools for teaching. These challenges likely were also faced by many developmental instructors who, as noted, were unlikely to have had formal training in instruction and were subject to lower levels of institutional acclimation and involvement (Schibik \& Harrington, 2004). Generational theory provides an underexplored framework that could provide further insight into instructors' affinity (or lack thereof) for the use of technology in teaching and learning. 


\section{Theoretical Framework}

Generational theory proposes that groups are a social structure shaped by "shared experiences, hardships, social norms, and turning points" (Lovely \& Buffum, 2007, p. 3). At least two ways of understanding these social structures have been posited. Howe and Strauss (2000) proposed that generations are cyclical in nature. Their theoretical lens conceives generational characteristics as four generational cohort types that reoccur approximately every 80 years. On the other hand, Twenge (2006) proposed that generational cohorts are linear in nature, and specifically more narcissistic with each passing generation. Regardless of whether the generational cohort pattern is cyclical or linear in nature, researchers have agreed that generational cohorts share a common bond. As expressed by Zemke, Ranes, and Filipczak (2000),

The first headlines to inspire and awe, to horrify and thrill, to send the imagination soaring or cause dark contemplation and heated conversation... [the] music..., the heroes..., the passions they agree or disagree about, and their common history shape and define a generation. Not that every individual fits that generation's personality profile to an exact "fare thee well." Some embody it; some spend a lifetime trying to live it down. Either way, all members of a generation are deeply affected by the personality of their cohort grouptheir generation (p. 16).

\section{Characteristics of Generations}

The generational groups examined here are those present in the workforce today-the Silent Generation (1927-1945), Baby Boomers (1946-1964), Generation Xers (1965-1983), and the Millennials (1984-2002). In a recent study Twenge, Campbell, and Freeman (2012) stated "at base, generational differences are cultural differences: As cultures change, their youngest members are socialized with new and different values" (p. 1045). The underlying assumption to the present research is that technology has changed across generations and as such has been a part of the cultural differences experienced by its members. Cultural critic Neil Postman (1993) notes the ties between culture and technology by stating "apart from their economic implications, technologies create the ways in which people perceive reality, and that such ways are the key to understanding diverse forms of social and mental life" (p. 21). As such, in addition to an elaboration of the characteristics ascribed to each generational cohort, a brief description of the related technology follows.

\section{The Silent Generation}

In 2014 members of the Silent Generation, also known as Radio Babies, were between 69 to 87 years old. Members of this group worked in environments with hierarchical structures and believed that dedication, hard work, and sacrifice paid off (Broom, 2010). Although respected for their ability to mediate and help others, this generation is notorious for not having had a member of this generational cohort as president (Strauss \& Howe, 1991). Instead, this generation has produced "America's greatest generation of comedians, psychiatrists, and songwriters" (Strauss \& 
Howe, 1991, p. 282). In 1964, when this generation was graduating from college, $16 \%$ of Harvard's graduating class joined the Peace Corps. Indeed the Silent Generation members are the "consummate helpmate generation" (Strauss \& Howe, 1991, p. 279).

\section{The Baby Boomers}

In direct contrast to the disposition of the Silent Generation, the Baby Boomers are known for doing "more, better, faster" (Effective Teaching and Learning, n.d., p. 19). In 2014, Baby Boomers were between 50 and 68 years old. Strauss and Howe (1991) coined this generation the "idealist" generation (p. 299). The Boomer generation grew up as dearly loved and protected children of the post-World War II era. Perhaps it is not surprising then that this generation typically is considered to have "an impatient desire for personal satisfaction, and weak civic instincts" and thus characterized as arrogantly favoring personal satisfaction and individual needs above community (Strauss \& Howe, 1991, p. 312).

\section{The Generation Xers}

In 2014, the Boomers and the Xers made up the majority of the workforce. The Xers distinguish themselves from the previous generation, in that they do not subscribe to the workaholic mentality of their predecessors. Instead, Xers are much more prone to seek a balance between work and life. In 2014, the Xers were between 31 and 49 years old. Polar opposite to being the guarded youth of the Boomers, Xers were known as latchkey kids, often in the home alone after school waiting on their workaholic Boomer parents to arrive (Strauss \& Howe, 1991). Perhaps because of the stark contrast between the two generations, the Xers were identified as slackers, and were the first generation to be less educated than their parents. Generation Xers are not likely to remain in one job or even in a career for an extended period. In fact, at minimum, they are expected to change jobs at least five times and industries at least three times throughout their career (Mocke, n.d.). This is not so much an issue of loyalty as it is an issue of survival, as noted by Strauss and Howe (1991), this generation has "built a powerful survival instinct, wrapped around an ethos of personal determinism" (p. 322).

\section{The Millennials}

Although the Baby Boomers grew up loved and protected, Millennials grew up as the prominently esteemed children of the Xers. The parents of this "special" generation proudly displayed "Baby on Board" signs on their automobiles (Strauss \& Howe, 1991). In 2014 the Millennials, also known as digital natives (Prensky, 2001), were between 12 and 30 years old. They arguably are the most physically and medically well cared for generation. The Millennials are also the most ethnically diverse generation to date (Strauss \& Howe, 1991). It is important to note that although this generation grew up with technology and is comfortable with multitasking and multimedia entertainment (Székely, \& Nagy, 2011), they are not necessarily media savvy (Considine, Horton, \& Moorman, 2009). 


\section{Technology by Generation}

Although not specific to a generational period, Reiser (2001) chronicled the history of instructional media, which makes possible the understanding of what technologies were available by generational classification. When the Silent Generation members were growing up, technological advances such as radio and sound motion pictures led to the "audiovisual instruction movement" (Reiser, 2001, p. 56). Baby Boomers were also taught with instructional films, but instructional television soon became more prevalent (Reiser, 2001). Computers began to appear in schools during the early 80s when some of the GenXers were in school, but did not become ubiquitous until the Millennials went to school. The explosion in technology tools since the 80s has been phenomenal. Although an understanding of what instructional media were available by generational cohort is helpful, it is not necessarily what they will encounter in the workplace. Professional development, both formal and informal, is necessary for all educators to maintain facility with the latest instructional technologies (Epper \& Baker, 2009).

Because technology will continue to evolve, gathering information about the use and integration of educational technology in classrooms is of international importance. Lichy (2012) conducted a study on students' behaviors towards the internet with a particular focus on social networking sites with data collected at partner institutions in France and Russia. While that study focused on within generational characteristics versus between generation characteristics, a conclusion was made that "an equally interesting field to explore would be teachers' attitudes to integrating SNS [social networking sites] into the curriculum, looking at how teachers choose (or choose not) to develop technology-led learning" (Lichy, 2012, p. 12). In addition, in an international study, Owston (2007) found that sustainability of pedagogical innovations that employed technology was contingent on the teacher. In particular, sustainability required "teacher and student support of the innovation, teacher perceived value of the innovation, teacher professional development, and principal approval" (p. 61). In a review spanning over twenty years of educational technology research trends in Turkey, the authors noted that faculty members were rarely (6\%) the sample of interest (Kucuk, Aydemir, Yildirim, Arpacik, \& Goktas, 2013). Instead, pre-service teachers and other undergraduate students were the most commonly researched groups (Kucuk et al. 2013). Therefore, with the realization that technology requires teacher support yet developmental mathematics faculty from different generational groups probably encountered different learning and training experiences with technology and the knowledge that this faculty group as a whole has not often been researched, the present study investigated faculty members' self-reported use of and beliefs about educational technology by generational classification.

\section{Research Questions}

The purpose of this research is to understand the impact that generational differences can have on developmental education faculty members' self-reported familiarity, use, and challenges with instructional technology as measured by the Developmental Education Technology Survey (DETS; Skidmore, Saxon, Zientek, \& Edmonson, 2012). To this end, the following research questions were examined: 
- What is the relationship between generational classification and developmental education faculty members' self-reported levels of familiarity with instructional technology, controlling for teaching status, years of experience, and K-12 certification status?

- How do developmental education faculty members' self-reported uses of campus computer laboratory facilities vary by generational classification?

- If time and resources were not a concern, what kind of instructional technology would developmental education faculty members like to use?

- What are the perceived challenges to the use of instructional technology as reported by developmental education faculty members by generational classification?

- How do developmental education faculty members' perceived technological skill level relate to generational classification when controlling for teaching status, years of experience, and K12 certification status?

\section{Method and Data Sources}

The Developmental Education Program Survey (DEPS) was developed to provide a description of the ways in which developmental education was being implemented in post-secondary programs across Texas (Texas Higher Education Coordinating Board, 2011). Although the DEPS did provide some descriptive information about the use of technology in developmental education programs, the focus was broad and not specific to the integration of technology in developmental education courses. On the other hand, the Developmental Education Technology Survey (DETS) was specifically designed to provide more information about the present state of technology integration in developmental education across Texas (Skidmore et al., 2012). In addition to faculty demographics, the instrument consisted of five major sections, including (a) faculty attitudes and perceptions; (b) technology in developmental education courses (c) professional development for instructional technology; (d) instructional technology challenges; and (e) technology tools. The latter section included hardware and commonly used software; content delivery tools; collaborative tools; communication tools; and online resources. The questionnaire included single response and multiple response options for close-ended items in addition to open-ended items that allowed participants to provide more in-depth responses. Additional details about the development of the instrument can be reviewed in the grant report (Skidmore et al., 2012).

The present study is part of a larger report to the Texas Higher Education Coordinating Board on the state of technology integration in developmental education. Therefore, the DETS was distributed electronically to the 98 institutions that participated in the DEPS in 2011. A contact person at each institution distributed the survey link to developmental education faculty members. A total of 70 institutions (with 890 developmental education faculty respondents) participated in the DETS for an institutional response rate of $71.4 \%$. A total of 753 respondents from 68 institutions (69.4\% institutional response rate) indicated their generational classification and are the sample included in the present study. Demographic characteristics of the present sample are displayed in Table 1. 
The items that asked (a) if respondents were teaching developmental courses, (b) if respondents were teaching online or hybrid courses, and (c) what content area they were teaching were the only required items on the DETS. Items of interest in the present study include instructional technology familiarity (FAMILIAR; 1 item), use of technology based laboratory facilities (LAB_USE; 5 items), and challenges to using technology (CHALLENGE; 7 items).

FAMILIAR was a 5-point Likert scale item where 1 indicates the respondent reported they were extremely familiar and a 5 indicates the respondent reported they were not at all familiar with applications and uses of technology in the learning environment.

Table 1. Characteristics of Developmental Education Faculty Respondents

\begin{tabular}{llll}
\hline Characteristic & & $f$ & $\%$ \\
\hline Generational Group & Silent & 75 & 10.0 \\
& Boomers & 395 & 52.5 \\
& Generation X & 34.7 \\
& Millennials & 261 & 2.9 \\
Gender & Men & 22 & 24.7 \\
& Women & 186 & 74.8 \\
Teaching Status & Part-time/Adjunct & 563 & \\
& Full-time & & 48.7 \\
Total Years of DE & & 367 & 46.2 \\
Experience & 0 & 348 & \\
& 1-5 & & 8.2 \\
& 6-10 & 62 & 38.6 \\
& $10+$ & 291 & 22.2 \\
K-12 & Certified Teacher & 167 & 30.5 \\
Subject & Integrated Reading and Writing & 230 & 62.5 \\
& Mathematics & 32 & 4.2 \\
& Reading & 352 & 46.7 \\
& Writing & 213 & 28.3 \\
& & 189 & 25.1 \\
\hline
\end{tabular}

Note. $N=753$. For some characteristics participants chose not to respond, therefore the percentages do not sum to $100 \%$. Because some instructors taught in more than one subject area the percentages sum to greater than $100 \%$ in the subject category.

USE and CHALLENGE allowed for multiple responses so that respondents could select any or all of the applicable uses or challenges. LAB_USE consisted of five items, asking about the instructor's use of technology- based laboratory facilities for their development education classroom: (a) LAB_USE1, students are required to attend the computer lab a certain number of hours weekly, 
(b) LAB_USE2, specific assignments are required to be completed at the computer lab, (c) LAB_USE3, students are required to work with tutors at the computer lab, (d) LAB_USE4, students are informed about the lab and asked them to attend as needed, and (e) LAB_USE5, faculty member spends time in the lab alongside the students.

CHALLENGE consisted of seven items: (a) CHALLENGE1, chose not to use technology, (b) CHALLENGE2, instructor's low skill level, (c) CHALLENGE3, off task behavior, (d) CHALLENGE4, student's low skill level, (e) CHALLENGE5, inadequate technology support, (f) CHALLENGE6, obsolete technology equipment, and (g) CHALLENGE7, access to technology equipment. Additionally, instructors were asked if time and resources were not a concern, what instructional technology tool they would use that they were not currently using. This was an open-ended item.

Because the first and fifth research question were focused on understanding the relationship between multiple independent variables and single dependent variables, regression analyses were planned (Chatterjee \& Simonoff, 2013). Multiple regression and logistic regression analysis were planned to examine how respondents' generational classification was related to reported familiarity and challenges with instructional technology, controlling for instructors' characteristics. Instructor's characteristics included in the models were teaching status (TS; full-time or part-time), developmental education teaching experience ( $\mathrm{DE}_{\mathrm{YRS}} ; 0,1-5,6-10$, or $10+$ ), and certified $\mathrm{K}-12$ teacher status (CERT; had previously taught as a certified K-12 teacher or not). Generational classification (GEN) was given by the generational category corresponding to the respondent's year of birth (Silent, Boomers, Xers, and Millennials).

The second and fourth research questions were focused on evaluating how the usage and perceived challenges reported varied across generational groups. To measure the differences, $z$ tests for proportions were conducted. The $z$ tests for proportions evaluates whether two groups are statistically significantly different on some characteristic of interest. The third research question was an open-ended item querying instructors on the type of instructional tool they would like to use if time and resources were not a concern. The type of tools was categorized. If a respondent provided more than one instructional technology tool, each tool was categorized.

\section{Results}

\section{Familiarity with Instructional Technology}

The first research question examined faculty members' reported levels of familiarity with instructional technology. On average, faculty members generally perceived themselves to be fairly familiar $(M=2.25 ; S D=1.02)$ with instructional technology rating $(1$, extremely familiar; 5 , not at all familiar). The raw coefficients for the regression equation are as follows:

$$
\text { FAMILIAR }=2.48+-.24(\mathrm{TS})+.07\left(\mathrm{DE}_{\mathrm{YRS}}\right)+.06\left(\mathrm{CERT}_{\mathrm{K} 12}\right)+-.15(\mathrm{GEN})
$$

Regression results indicated that the included variables significantly predicted respondents' reported familiarity with instructional technology, $F(4,702)=6.07, p<.001, R^{2}=3.3 \%$. Moreover, generational classification was a statistically significant predictor $(\beta=-.10, p=.01)$, as was 
teaching status $(\beta=-.11, p<.01)$. The negative coefficient for generational classification indicates an inverse relationship existed between generational classification (older to younger) and degree of familiarity (extremely familiar to not at all familiar). Thus, younger generations reported more degree of familiarity with technology in the learning environment. The negative coefficient for teaching status indicated that full-time faculty $(F T=1 ; P T=0)$ on average, reported greater familiarity with instructional technology than part-time faculty. However, the practical significance was small, with the variables accounting for only $3.3 \%$ of the variance explained.

\section{Campus Computer Laboratory Facilities}

The second research question focused on differences in faculty members reported use of campus computer laboratory facilities across generational cohorts. The outcome of the $z$ tests are displayed in Table 2. Across the five items concerned with the use of campus computer lab facilities across generational groups, only the item on requiring students to spend a specified number of hours weekly was significantly different. A significantly greater proportion (42.3\%) of the Silent Generation developmental education instructors required their students to spend a specified number of hours weekly at the computer lab. Members of the Millennials were least likely (13.6\%) to require students to attend a specified number of hours per week.

Table 2. Campus Computer Laboratory Use by Generation Cohort Status

\begin{tabular}{|c|c|c|c|c|c|c|c|c|}
\hline \multirow{2}{*}{$\begin{array}{l}\text { Use of Computer Lab } \\
\text { Students informed about availability } \\
\text { for support as needed for use on their } \\
\text { own time. }\end{array}$} & \multicolumn{2}{|c|}{$\begin{array}{l}\text { Silent } \\
\text { Generation }\end{array}$} & \multicolumn{2}{|c|}{ Baby Boomers } & \multicolumn{2}{|c|}{$\begin{array}{l}\text { Generation } \\
\text { Xers }\end{array}$} & \multicolumn{2}{|c|}{ Millennials } \\
\hline & $48 a$ & $67.6 \%$ & $259 a$ & $69.1 \%$ & $178_{a}$ & $70.4 \%$ & $17 \mathrm{a}$ & $77.3 \%$ \\
\hline Instructor in lab with students. & $38 a$ & $53.5 \%$ & $177_{\mathrm{a}}$ & $47.2 \%$ & $118_{a}$ & $46.6 \%$ & $12_{\mathrm{a}}$ & $54.5 \%$ \\
\hline $\begin{array}{l}\text { Students required to attend to } \\
\text { complete specific assignments on their } \\
\text { own time. }\end{array}$ & $18 \mathrm{a}$ & $25.4 \%$ & $103_{a}$ & $27.5 \%$ & $77 \mathrm{a}$ & $30.4 \%$ & $7 \mathrm{a}$ & $31.8 \%$ \\
\hline $\begin{array}{l}\text { Student required to attend for a } \\
\text { specified number of hours weekly. }\end{array}$ & $30_{a}$ & $42.3 \%$ & 100 & $26.7 \%$ & $70_{b}$ & $27.7 \%$ & $3_{b}$ & $13.6 \%$ \\
\hline $\begin{array}{l}\text { Students required to attend and work } \\
\text { with tutor/faculty/instructional } \\
\text { assistants. }\end{array}$ & $7 \mathrm{a}$ & $9.9 \%$ & $60_{a}$ & $16.0 \%$ & $42_{a}$ & $16.6 \%$ & $2 \mathrm{a}$ & $9.1 \%$ \\
\hline
\end{tabular}

Note. Silent, $N=71$; Boomers, $N=375$; Xers, $N=253$; Millennials, $N=22$. Using the $z$ test to estimate the difference between proportions, each subscript letter denotes a subset of the generational status categories whose row proportions do not differ significantly from each other at the .05 level.

In contrast, consistent across generational cohorts the top two most frequently reported uses of campus computer laboratory facilities were: (a) informing the students about the availability for 
support as needed on their own time $(67.6 \%-77.3 \%)$ and, (b) the instructor present in the lab with the students (46.6\% - 54.5\%). Approximately $40 \%$ of the members of each generational group reported at least one lab use, and roughly $25 \%$ reported two lab uses.

\section{Desired Instructional Technology Tools}

The third research question was descriptive in nature. These open-ended questions allowed faculty members to indicate the type of instructional technology tool(s) they would like to use if time and resources were not a concern; all responses were categorized. If a respondent provided more than one instructional technology tool, each tool was categorized. The categories of tools that were most frequently listed are provided in Table 3. Percentages are based on the number of generational cohort respondents. Categories not included contained tools that $3 \%$ or fewer of the faculty respondents indicated they would want to use. The most frequently requested tool across all generations, except for the Silent, was a Smartboard or Interactive Whiteboard. Other notable differences by generations were observed. For example, Xers and Millennials more frequently requested Audience Response Systems or Clickers while Boomers seemed more interested in Tablets. Silent Generation members most frequently reported that they did not know what tool to request.

Table 3. Instructional Tools Developmental Faculty Would Like to Use

\begin{tabular}{|c|c|c|c|c|c|c|c|c|c|c|c|c|c|c|}
\hline \multirow{2}{*}{ Generation } & \multicolumn{2}{|r|}{1} & \multicolumn{2}{|r|}{2} & \multicolumn{2}{|c|}{3} & \multicolumn{2}{|r|}{4} & \multicolumn{2}{|c|}{5} & \multicolumn{2}{|c|}{6} & \multicolumn{2}{|c|}{7} \\
\hline & Cnt & Pct & Cnt & Pct & Cnt & Pct & Cnt & Pct & Cnt & Pct & Cnt & Pct & Cnt & Pct \\
\hline Silent & 5 & $14.3 \%$ & 2 & $5.7 \%$ & 2 & $5.7 \%$ & 3 & $8.6 \%$ & 2 & $5.7 \%$ & 1 & $2.9 \%$ & 8 & $22.9 \%$ \\
\hline Boomers & 54 & $25.5 \%$ & 17 & $8.0 \%$ & 29 & $13.7 \%$ & 27 & $12.7 \%$ & 14 & $6.6 \%$ & 15 & $7.1 \%$ & 16 & $7.5 \%$ \\
\hline Xers & 27 & $19.1 \%$ & 25 & $17.7 \%$ & 12 & $8.5 \%$ & 18 & $12.8 \%$ & 10 & $7.1 \%$ & 6 & $4.3 \%$ & 14 & $9.9 \%$ \\
\hline Millennials & 3 & $16.7 \%$ & 3 & $16.7 \%$ & 1 & $5.6 \%$ & 1 & $5.6 \%$ & 0 & $0.0 \%$ & 1 & $5.6 \%$ & 2 & $11.1 \%$ \\
\hline
\end{tabular}

\section{Challenges to the Use of Instructional Technology}

The fourth research question examined an instructor's reported challenges to the use of instructional technology in a developmental education classroom across generational cohorts. The outcome of the $z$ tests is displayed in Table 4. Across the generational groups, student's off-task behavior (43.3\% - 56.6\%) and student's low technology skills $(34.0 \%-60.0 \%)$ were most frequently reported as challenges to the use of technology in the developmental education classroom. Differing statistically significantly by generational classification were student's low technology skills, instructor's self-reported low technology skills, and technology support. The older the instructor's generational classification the more likely he or she chose instructor's low technology skills as a challenge (Silent, 28.3\%; Boomers, 10.7\%; Xers, 4.1\%; and Millennials, 5.0\%). The younger the instructor's generational classification the more frequently he or she indicated student's low technology skills (Silent, 34.0\%; Boomers, 45.0\%; Xers, 43.3\%; and Millennials, $60.0 \%$ ) and technology support (Silent, 3.8\%; Boomers, 16.3\%; Xers, 20.6\%; and Millennials, 
$25.0 \%)$ to be problematic. Roughly half of the members of each generational group reported at least one challenge and roughly a third reported two challenges.

The focus of the final research question was on instructor's technology skill level as a perceived challenge across generational cohorts controlling for TS, DE $E_{Y R S}$, and CERT $T_{K 12}$. Because the outcome variable was dichotomous, a logistic regression model was conducted. The logistic regression equation can be expressed as follows:

$$
\text { In(odds) TECH_SKILL }=-.63+.54(\mathrm{TS})+.08\left(\mathrm{DE}_{\mathrm{YRS}}\right)+-.15\left(\mathrm{CERT}_{\mathrm{K} 12}\right)+-.96(\mathrm{GEN})
$$

Table 4. Reported Challenges in Using Technology by Generational Status

\begin{tabular}{|c|c|c|c|c|c|c|c|c|}
\hline \multirow{2}{*}{$\begin{array}{l}\text { Technological } \\
\text { Challenges }\end{array}$} & \multicolumn{2}{|c|}{$\begin{array}{c}\text { Silent } \\
\text { Generation }\end{array}$} & \multicolumn{2}{|c|}{ Baby Boomers } & \multicolumn{2}{|c|}{$\begin{array}{c}\text { Generation } \\
\text { Xers }\end{array}$} & \multicolumn{2}{|c|}{ Millennials } \\
\hline & Cnt & Pct & Cnt & Pct & Cnt & Pct & Cnt & Pct \\
\hline $\begin{array}{l}\text { Student's technology } \\
\text { skills }\end{array}$ & $18_{\mathrm{a}}$ & $34.0 \%$ & $130_{a, b}$ & $45.0 \%$ & $84_{a}$ & $43.3 \%$ & $12_{b}$ & $60.0 \%$ \\
\hline $\begin{array}{l}\text { Student's off-task } \\
\text { behavior }\end{array}$ & $30_{a}$ & $56.6 \%$ & $125 a$ & $43.3 \%$ & $90_{a}$ & $46.4 \%$ & $11_{\mathrm{a}}$ & $55.0 \%$ \\
\hline Inadequate Access & $15_{a}$ & $28.3 \%$ & $107_{a}$ & $37.0 \%$ & $80_{a}$ & $41.2 \%$ & $7 \mathrm{a}$ & $35.0 \%$ \\
\hline Technology support & $2 a$ & $3.8 \%$ & $47_{b}$ & $16.3 \%$ & $40_{b}$ & $20.6 \%$ & $5 b$ & $25.0 \%$ \\
\hline Obsolete Equipment & $5 a$ & $9.4 \%$ & $35 a$ & $12.1 \%$ & $28_{a}$ & $14.4 \%$ & $4 a$ & $20.0 \%$ \\
\hline Chose not to use & $8 a$ & $15.1 \%$ & $31_{\mathrm{a}}$ & $10.7 \%$ & $19_{a}$ & $9.8 \%$ & $2 a$ & $10.0 \%$ \\
\hline $\begin{array}{l}\text { Instructor's } \\
\text { technology skills }\end{array}$ & $15_{\mathrm{a}}$ & $28.3 \%$ & $31_{b}$ & $10.7 \%$ & $8 \mathrm{c}$ & $4.1 \%$ & $1_{b, c}$ & $5.0 \%$ \\
\hline
\end{tabular}

Note. Silent, $N=53$; Boomers, $N=289$; Xers, $N=194$; Millennials, $N=20$. Using the $z$ test to estimate the difference between proportions, each subscript letter denotes a subset of the generational status categories whose row proportions do not differ significantly from each other at the .05 level. Instructors could mark multiple responses. Cnt $=$ Count; Pct $=$ Percent.

The results provided in Table 5 illustrate that generational classification was a statistically significant predictor $(p<.001)$. The reported Nagelkerke (1991) $R^{2}$, also known as a pseudo $R^{2}$, as it is analogous to the traditional $R^{2}$ effect size that is interpreted as the proportion of explained variation, was considered noteworthy $\left(R^{2}=.101\right)$.

Table 5. Logistic Regression Analysis Predicting Challenge of Skill Level

\begin{tabular}{lrrrrr}
\hline Predictor & $\mathrm{B}$ & $\mathrm{SE}$ & $p$ & $O R$ & $95 \% \mathrm{Cl}$ \\
\hline Full-time & .538 & .333 & .106 & 1.713 & {$[0.892,3.288]$} \\
Years of experience in DE & .082 & .173 & .634 & 1.086 & {$[0.774,1.523]$} \\
Certified Teacher & -.148 & .327 & .651 & .863 & {$[0.455,1.637]$} \\
Generational classification & -.959 & .248 & $<.001$ & .383 & {$[0.236,0.623]$} \\
\hline
\end{tabular}

Note. $N=521 . \mathrm{Cl}=$ confidence interval for odds ratio $(O R)$. Nagelkerke $R^{2}=.101$.

Another way to understand the practical significance of the difference across generational groups is to use the odds ratio. The odds ratio allows for a quantification of the degree to which the 
groups differed. The odds for a generational group member to indicate low instructor skill level as a challenge is simply the number of members who indicated yes to their own skill level as a challenge compared to those who did not indicate yes to their own skill level as a challenge. The odds for any two groups can then be compared. For example, 15 out of 38 (.395) of the Silent Generation members indicated their own skill level was a challenge; whereas 1 out of 19 (.053) members of the Millennials indicated their own skill level was a challenge. Therefore the magnitude of the ratio $(.394 / .053=7.50)$ is interpreted as follows: the odds for the Silent Generation members reporting their own skill level as a challenge were 7.50 times larger than the odds of the Millennials reporting the same. Similar calculations for the other generational groups results in odds for members of the Silent Generation being 3.29 times higher than members of the Boomer Generation. In comparison to the Xers, the odds for members of the Silent Generation were 9.18 times larger. The odds of Boomers were 2.79 times larger than the odds for the members of the Xer generation. The odds of Boomers were 2.28 times greater than that of Millennials.

\section{Discussion}

Understanding instructor's perceived familiarity with and uses of technology provides researchbased insight about how technology is utilized in classrooms. This information can further inform stakeholders about the type of professional development that can be beneficial for faculty. Even though faculty may be introduced to technology outside of the classroom, the use of technology might not transcend into use of technology for instructional purposes. This research further provides instructors' noted challenges with technology in the classroom.

In an international study, Owston (2007) concluded that " unless teachers ultimately see students benefiting from an innovation or other evident advantages of the innovation, the likelihood is small of them being motivated to sustain it even with" additional support "or policy directives" (p. 75). This conclusion is consistent with Jefferies et al. (2013) factors of performance expectancy and facilitating conditions as "direct determinants of behavioural intentions and thus the actual personal usage of technology" (p. 23). Therefore, the successful implementation of universal or local policies is dependent on faculty members. In the present study, overall, faculty members rated themselves as being fairly familiar with applications and uses of technology in the learning environment. Generational classification was statistically significantly related to faculty members' reported familiarity with instructional technology controlling for instructors' characteristics (teaching status, years of experience in developmental education, and having taught as a certified $\mathrm{K}-12$ teacher). Younger faculty members on average reported greater familiarity with technology in the learning environment than older faculty members. Perhaps, this is a reflection of the skepticism older faculty have with regard to the use of instructional technology. Jorn et al. (2003) reported that older faculty members expressed issues such as increased time, inadequate support, and lack of skills as barriers to learning and applying instructional technology applications. Furthermore, they were skeptical about using technology unless they had thought through how student learning would be impacted and how their pedagogy would be enhanced. 
Irrespective of generational status, faculty members were generally similar in how they chose to use campus technology based laboratory facilities. Roughly 7 out of every 10 instructors by generational cohort reported that they informed students about the availability of the campus computer lab for their use as needed. Notifying students about the availability of computers for their use is simple to do. Researchers have noted that users prefer technology that is "simple, easy to use, convenient and free" (Flavin, 2013, p. 8). Further, approximately half reported that as an instructor, they were present in the computer lab with their developmental education students. These results may be indicative of local policies. What did vary by generational status was the requirement that students spend a specified number of hours weekly in the lab. A statistically significant greater proportion of Silent Generation faculty members required students to spend a specified number of hours weekly in the lab. Though speculative, it may be considered that older faculty members are more familiar with the availability of campus laboratory support services. They may also be aware of the research suggesting that these types of support services are known to increase student success rates in developmental courses (Boylan, 2002). Based on this research, it seems important that laboratory activities and classroom instruction be well integrated. As a result, developmental education instructors should be trained to utilize lab facilities and to spend time in the labs working with students.

As noted previously, all of the questions on the DETS were optional except for those that asked if the instructors were teaching developmental courses, online or hybrid courses, and the instructor's content area. Of the instructors who decided to respond to the open-ended item that allowed them to input the type of instructional tools that they would like to use if time and resources were not a concern, the most frequently chosen response of Boomers, Xers, and Millennials was Smartboards (e.g., interactive whiteboards). The most frequently chosen response of the Silent generation was "Don't Know." The latter response suggests that some members of the Silent generation might not know the benefits of some of the newer technologies. Another frequently chosen response of Xers and Millennials was Audience Response Systems (e.g., classroom response systems or "clickers"). The existing literature supports the use of interactive white boards and classroom response systems as tools used to engage and motivate students, but both require changes in pedagogy (see Caldwell, 2007; Manny-lkan, Tikochinski, Zorman, \& Dagan, 2011). For example, challenges for implementing interactive whiteboards have been identified by instructors in a study by Manny-lkan et al. (2011). In addition, classroom response systems tend to result in less content coverage that is compensated by improved student learning and teachers' understanding of student difficulties (see discussion by Caldwell, 2007). To be effective in increasing student engagement, motivation, and achievement, professional development for instructors is necessary (Epper \& Baker, 2009; Manny-lka et al., 2011). Therefore, the effective use of these technologies will require that developmental education instructors have access to thoughtful training that is research-based. A framework based on Keller's (1983) Attention, Relevance, Confidence, Satisfaction Model of Motivation is one option to help support and motivate faculty members to use technology in the classroom (c.f. Surry \& Land, 2000).

Faculty members, regardless of generational cohort status, most often reported students' off-task behavior as challenge to their use of technology in developmental education classrooms. These results were similar to the findings with a sample of middle school and high school teachers (Zientek, Matteson, Mittag, \& Taylor, 2010). Notable differences across generational groups were 
found in other challenge categories. First, Silent Generation members were statistically significantly less likely to report students' technology skill level as a challenge than the younger Millennial cohort members. Silent Generation members were also statistically significantly different than all the other generational groups in terms of their tendency to report insufficient or inadequate technology support. Indeed less than $4 \%$ of the members of the Silent Generation reported technology support as a challenge. In contrast, younger generational cohort members increasingly noted technology support as a challenge, with Millennials reporting this challenge item one-fourth of the time. Likewise, Millennials were statistically significantly more likely than members of the Silent Generation to choose student's low technology skills as a challenge to the use of instructional technology. Whereas roughly 3 out of every 10 members of the Silent Generation chose student's low technology skills as a challenge, 6 out of every 10 members of the Millennials consider this an area of concern.

In decreasing frequency by generational status, instructor's self-reported low technology skill level was a statistically significant challenge area. Over a quarter of the faculty members of the Silent Generation noted their own low technology-skill level as a challenge whereas only $5 \%$ of the Millennials noted the same. Indeed, logistic regression results indicated instructors' generational classification was the best predictor in the model for this challenge item. Comparison of the odds of a Silent Generation faculty respondent indicating that his or her own low skill level was a challenge differed markedly across the other generational groups. This difference was most pronounced with the Xers (odds of Silent 9.18 times as large as odds of Xers) and the Millennials (odds of Silent 7.5 times as large as odds of Millennials).

\section{Limitations}

Studies are not without limitations; limitations of this study are offered here. Whereas the DEPS allowed only one contact person per school to respond for the developmental education program, input was sought from all developmental faculty members in the DETS. Because it was important to maintain the anonymity of these instructors, a contact person at each school distributed the survey via email to the developmental education faculty members using a school-specific link. Thus, a response rate was reported at the institutional level only.

Another limitation pertains to the researchers' choice to make the majority of the survey items optional. Forcing study participants to respond can create biased responses because respondents may not want to respond or may not have the information available to respond. Additionally, respondents may not feel that the question applies to them or their preferred response option may not be listed. The tradeoff for allowing respondents to be able to choose which questions to respond to is the resulting differences in response rates per item. The reader will note the sample size provided in the tables differs by item. To be clear, $N$ s for total sample size and/or per generational class were provided as appropriate. To state with certainty why respondents chose not to respond to particular items is not possible. Although survey fatigue can account for some of the lack of response, respondents could have also chosen not to respond due to the abovementioned reasons. 
The use of computer laboratory facilities is required on many college campuses. We did not ask specifically about local campus computer usage policies. Therefore, as indicated in the discussion, variations in campus computer facilities usage may be due in part to local policies.

Although we examined the results of our study through the lens of generational status, we recognize that not every member of a generational cohort is identical in their propensities to use (or not use) technology. It is not our intent to rate generational cohorts based on their technology usage, but simply to describe general patterns observed.

Finally, this research was subject to the limitations of self-reported data. Information collected in this manner is subject to challenges with regard to personal bias, as well as perceptual and recall disparities.

\section{Conclusion}

The use of technology by students in their everyday lives is now a norm, and the existence of instructional technology in the classrooms is an expectation. As noted by Mary Ann Wolf, the former Executive Director of State Educational Technology Directors Association, "well-executed, technology rich classroom environments increase student achievement and engagement, boost teacher retention rates, and reduce discipline referrals" (Education News, 2009, p. 1). The next generation of students presumes learning will occur through the use of a variety of technology tools (Geer \& Sweeney, 2012). Our focus in this paper has been on delivery methods and not on identifying "what works" (Ross, Morrison \& Lowther, 2010). Nonetheless, as noted by Ross, Morrison, and Lowther (2010) the integration of computers has demonstrated increases in such areas as "student-centered, cooperative, and higher-order learning; student skills in writing, problem solving, and using technology; positive attitudes towards technology ..." (p.21). We recognize that what teachers believe about technology is often aligned with their practices (Ertmer, 2012) research. In other words, "teachers who believe that technology provided more opportunities for student choice, described examples in which students chose to demonstrate their learning using a variety of technology tools" (p. 432). Therefore, it is critical not only to understand what teachers attitudes and beliefs toward technology are but also to understand is the importance of provide facilitating conditions, as described by Jefferies et al.(2013) to promote the integration of technology.

Texas state legislators have affirmed the application of instructional technologies in the developmental education classroom. Indeed Ross and Lowther (2009) noted the value of using computer assisted instruction to help low-achieving students. As the use of technology is promoted and as in the case of Texas, mandated as a tool for enhancing teaching and learning, the differences among generational groups of teachers is a factor worthy of consideration in identifying what tools are used and how they are applied effectively. It appears in this work that nearly $63 \%$ of the sample of developmental education teachers is older than the age of 49 . Understanding the reservations and concerns of these teachers will enable administrators and instructional technology professionals to procure and promote those technology tools that are more likely to be used and applied effectively in the developmental education classroom. In 
addition, an understanding of the diverse backgrounds of developmental instructors will enable professional development and training needs to be better tailored to their needs and desires.

\section{Acknowledgement}

This project was supported in part by a grant from the Texas Higher Education Coordinating Board (Grant No. 07272).

\section{References}

Boatman, A. (2014). Beyond ready, fire, aim: New solutions to old problems in college remediation. Retrieved on 10 January 2014 from http://www.aei.org/files/2014/03/25/-beyond-readyfire-aim-new-solutions-to-old-problems-in-college-remediation_085930704998.pdf

Boylan, H. R. (2002). What works: Research-based best practices in developmental education. Boone, NC: National Center for Developmental Education.

Boylan, H. R. (2009). The mistakes we make and how we correct them: What l've learned as a consultant. NADE Digest, 4(2), 1-8.

Broom, C. (2010). Entice, engage, endure: Adapting evidence-based retention strategies to a new generation of nurses. Journal of Healthcare Leadership, 2, 49-60. doi:10.2147/JHL.S7914

Caldwell, J. E. (2007). Clickers in the large classroom: Current research and best-practice tips. CBELife Sciences Education, 6(1), 9-20. doi:10.1187/cbe.06-12-0205

CDW-G. (2011). The 2011 CDW-G 21st-century campus report. Retrieved on 26 November 2013 from http://download.1105media.com/CAM/conf/2011/Presentations/T09_AndrewLausch_The-21st-Century-Campus-Students-Tell-It-Like-It-Is_07-26-201.pdf

Chatterjee, S., \& Simonoff, J. S. (2013). Handbook of regression analysis. Hoboken, NJ: John Wiley \& Sons.

Considine, D., Horton, J., \& Moorman, G. (2009). Teaching and reaching the millennial generation through media literacy. Journal of Adolescent \& Adult Literacy, 52, 471-481. doi: 10.1598/JAAL.52.6.2

Education News. (2009, February). Stimulus package sees education technology's importance to U.S. competitiveness. Retrieved on 29 August 2013 from http://ednews.org/articles/ 34125/1/Stimulus-Package-Sees-Education-Technologys-Importance-to-USCompetitiveness/Page1.html

Effective Teaching and Learning. (n.d.). Teaching across generations. Retrieved on 1 November 2013 from http://www.mcc.edu/pdf/pdo/teaching_across_gen.pdf

Epper, R. M., \& Baker, E. D. (2009, January). Technology Solutions for developmental math: An overview of current and emerging practices. Retrieved on 2 April 2013 from http://www. gatesfoundation.org/learning/Documents/technology-solutions-for-developmental-mathjan-2009.pdf 
Ertmer, P. A., Ottenbreit-Leftwich, A. T., Sadik, O., Sendurur, E., \& Sendurur, P. (2012). Teacher beliefs and technology integration practices: A critical relationship. Computers \& Education, 59(2), 423-435. doi:10.1016/j.compedu.2012.02.001

Flavin, M. (2013). Disruptive conduct: the impact of disruptive technologies on social relations in higher education. Innovations in Education and Teaching International (ahead-of-print), 113. doi:10.1080/14703297.2013.866330

Garrison, D. R., \& Akyol, Z. (2009). Role of instructional technology in the transformation of higher education. Journal of Computing in Higher Education, 21, 19-30. doi:10.1007/s12528-0099014-7

Geer, R., \& Sweeney, T. A. Students' voices about learning with technology. Journal of Social Sciences, 8, 294-303.

Green, K. C. (1996). The coming ubiquity of information technology. Change, 28(2), 24-31. doi: 10.1080/00091383.1996.9937746

Howe, N., \& Strauss, W. (2000). Millennials rising: The next generation. New York, NY: Vintage Books.

Jefferies, A., Cubric, M., \& Russell, M. (2013). Enhancing learning and teaching using electronic voting systems-The development of a framework for an institutional approach for their introduction. Cutting-edge technologies in higher education, 6, 17-45. doi:10.1108/S20449968(2013)000006E004

Jorn, L., Martyr-Wagner, M., Mendenhall, T., Molgaard, L., Oliver, J., Sonnack, J., Walker, J. D., (2003). Multi-college faculty survey: Experiences with educational technology at the University of Minnesota (2003). Retrieved on2 April 2013 from http://www.oit.umn.edu/ prod/groups/oit/@pub/@oit/@web/@evaluationresearch/documents/asset/oit_asset_ 149637.pdf

Keller, J. M. (1983). Motivational design of instruction. In Reigeluth, C. (Ed.) Instructional Design Theories and Models. Hillsdale, NJ: Lawrence Erlbaum.

Kucuk, S., Aydemir, M., Yildirim, G., Arpacik, O., \& Goktas, Y. (2013). Educational technology research trends in Turkey from 1990 to 2011. Computers \& Education, 68, 42-50. doi:10.1016/j.compedu.2013.04.016

Lichy, J. (2012). Towards an international culture: Gen Y students and SNS? Active Learning in Higher Education, 13, 101-116. doi:10.1177/1469787412441289

Lovely, S., \& Buffum, A. G. (2007). Generations at school: Building an age-friendly learning community. Thousand Oaks, CA: Corwin.

Manny-lkan, E., Tikochinski, T. B., Zorman, R., Dagan, O. (2011). Using the interactive white board in teaching and learning - An evaluation of the SMART CLASSROOM pilot project. Interdisciplinary Journal of E-Learning \& Learning Object, 7, 249-273.

Merrill, M. D. (2002). Effective use of instructional technology requires educational reform. Educational Technology, 17(2), 13-18. 
Meyer, K. A., \& Xu, Y. J. (2007). A Bayesian analysis of the institutional and individual factors influencing the faculty technology use. The Internet and Higher Education, 10, 184-195. doi:10.1016/j.iheduc.2007.06.001

Mocke, D. (n.d.). Understanding Generation X. Retrieved on 12 February 2013 from http://www.sustainable-employee-motivation.com/generation-X.html

Nagelkerke, N. J. D. (1991). A note on a general definition of the coefficient of determination. Biometrika, 78, 691-692. doi:10.1093/biomet/78.3.691

National Center for Education Statistics. (2003). Remedial education at degree-granting postsecondary institutions in Fall 2000. Washington, DC: U.S. Department of Education, Office of Educational Research and Improvement. Retrieved from http://nces.ed.gov/ pubs2004/2004010.pdf

Owston, R. (2007). Contextual factors that sustain innovative pedagogical practice using technology: An international study. Journal of Educational Change, 8, 61-77. doi:10.1007/s10833-006-9006-6

Postman, N. (1993). Technopoly: The surrender of culture to technology. New York: Vintage Books.

Prensky, M. (2001). Digital natives, digital immigrants: A new way to look at ourselves and our kids. On The Horizon, 9(5), 1-6. doi:10.1108/10748120110424816

Reiser, R. A. (2001). A history of instructional design and technology: Part I: A history of instructional media. Educational Technology Research and Development, 49(1), 53-64. doi:10.1007/BF02504506

Ross, S. M., Morrison, G. R., \& Lowther, D. L. (2010). Educational technology research past and present: Balancing rigor and relevance to impact school learning. Contemporary Educational Technology, 1(1), 17-35.

Ross, S. M., \& Lowther, D. L. (2009). Effectively using technology in education. Better EvidenceBased Education, 2(1), 20-21.

Salinas, M. F. (2008). From Dewey to Gates: A model to integrate psychoeducational principles in the selection and use of instructional technology. Computers \& Education, 50, 652-660. http://dx.doi.org/10.1016/j.compedu.2006.08.002

Salomon, G. (2002). Technology and pedagogy: Why don't we see the promised revolution? Educational Technology, 17(2), 71-75.

Schibik, T., \& Harrington, C. (2004). Caveat emptor: Is there a relationship between part-time faculty utilization and student learning outcomes and retention? AlR Professional File, 91, 110.

Shults, C. (2001). Remedial education: Practices and policies in community colleges. Washington, DC: American Association of Community Colleges.

Skidmore, S. T., Saxon, D. P., Zientek, L. R., \& Edmonson, S. L. (2012). Technology integration in developmental education in Texas. (Contract No. 07272). Austin, TX: Texas Higher Education Coordinating Board. 
Strauss, W., \& Howe, N. (1991). Generations: The history of America's future, 1584 to 2069. New York: William Morrow \& Company.

Surry, D. W., \& Land, S. M. (2000). Strategies for motivating higher education faculty to use technology. Innovations in Education and Teaching International, 37(2), 145-153. doi:10.1080/13558000050034501

Székely, L., \& Nagy, Á. (2011). Online youth work and eYouth-A guide to the world of the digital natives. Children and Youth Services Review, 33, 2186-2197. doi: 10.1016/j.childyouth.2011. 07.002

Texas Higher Education Coordinating Board. (2011). Developmental education program survey information. Retrieved on 30 January 2013 from http://www.thecb.state.tx.us/index.cfm? objectid=18555FEC-AF44-3B38-21A9F804FDBD3516

Texas House Bill 1244. 82nd Legislature. Regular session. (2011).

Twenge, J. M. (2006). Generation me: Why today's young Americans are more confident, assertive, entitled - and more miserable than ever before. New York: Free Press.

Twenge, J. M., Campbell, W. K., \& Freeman, E. C. (2012). Generational differences in young adults' life goals, concern for others, and civic orientation, 1966-2009. Journal of Personality and Social Psychology, 102, 1045-1062. doi:10.1037/a0027408

Zemke, R., Ranes, C., \& Filipczak, B. (2000). Generations at work: Managing the clash of Veterans, Boomers, Xers, and Nexters at your workplace. New York: AMACOM.

Zientek, L. R., Matteson, S. M., Mittag, K. C., \& Taylor, S. (2010, November). Evaluating the impact of virtual manipulatives on teacher quality. Paper presented at the annual meeting of the School Science and Mathematics Association. Fort Myers, Florida.

Correspondence: Susan Troncoso Skidmore, Assistant Professor, Department of Educational Leadership and Counseling, Sam Houston State University, Huntsville, Texas, United States 